\title{
A Comparative Assessment of ACCESS Auditor's Manual and ISO 9001:2015 Standards in the Perspective of Training on ISO 9001 to Cooperative Staff and Board Members
}

\author{
Tatwa P. Timsina ${ }^{1}$
}

\author{
${ }^{1}$ Professor, Tribhuvan University and Advisor, Institute of Innovation and Quality Assurance, \\ Kathmandu, Nepal. \\ Email: tatwa.timsina@gmail.com
}

\begin{abstract}
Cooperatives are people-centred enterprises owned, controlled and run by and for their members to realise their common economic, social, and cultural needs and aspirations. For the proper functioning of the cooperative, various tools such as ACCESS are used. ISO 9001 and similar standards are used for the proper management of the particular organisation. Both the approaches follow different sets of criteria to assess the level of organisation, but there are many similarities between them. They have focused on achieving sustainability and prosperity of the organisation by implementing such criteria in the organisation. This article has aimed to reveal such similarities and dissimilarities and proposed the way of implementing them in a holistic way.
\end{abstract}

\section{KEYWORDS}

ACCESS, Cooperatives, ISO 9001, ISO Standards, Management, Quality

\section{INTRODUCTION}

\section{Cooperative Movement: Global and Nepal Perspective}

Cooperatives are people-centred enterprises owned, controlled and run by and for their members to realise their common economic, social, and cultural needs and aspirations. Cooperatives bring people together in a democratic and equal way. Whether the members are the customers, employees, users or residents, cooperatives are democratically managed. Members share equal voting rights regardless of the amount of capital they put into the enterprise (COOP, 2020).

The cooperative movement in Nepal began with the establishment of the first cooperative - Bakhan Multi-purpose Cooperative Institute - in Chitwan way back in 1957 and the first Cooperative Act was enacted in 1960. The cooperative movement, however, did not pick up momentum until the 1980s, when a large number of community-based savings and credit cooperatives came up across Nepal. The Nepal Federation of Savings and Credit Cooperative Unions (NEFSCUN) was formed in 1988 (Maharjan, 2020). The cooperatives' contribution to the gross domestic product (GDP) is around 4 per cent, whereas their contribution to the financial 
sector stands at around 20 per cent. There are around 35,000 cooperatives in the country with 6.3 million members, out of which women constitute 50 per cent. Over 60,000 people are directly employed in cooperatives (Maharjan, 2020).

The earliest record of a co-operative at global level comes from Fenwick, Scotland where, in March 14, 1761, in a barely furnished cottage local weavers manhandled a sack of oatmeal into John Walker's whitewashed front room and began selling the contents at a discount, forming the Fenwick Weavers' Society. There is a plethora of records of co-operatives started out as small grassroots organisations in Western Europe, North America and Japan in the middle of the nineteenth century, however, it is the Rochdale Pioneers that are generally regarded as the prototype of the modern co-operative society and the founders of the Co-operative Movement in 1844 (COOP, 2020). An independently formulated co-operative model developed in Germany by Friedrich Wilhelm Raiffeisen and Franz Hermann Schultz-Delitsch. Raiffeisen and SchultzDelitsch originally formed credit unions in 1862. Since then the model has grown into other sectors and inspired the growth of financial co-operatives across the world. Today the sector is estimated to have around 1 billion members. Co-operatives employ, directly or indirectly, 250 million people around the world. The world's top 300 co-operatives by themselves have an estimated global turnover of 2.2 trillion USD, as revealed by the 2014 World Co-operative Monitor (COOP, 2020).

\section{ISO for Prosperity}

Quality management system through establishment and implementation of ISO and other standards are suitable for both small and large organisations as it helps in improving the internal management. Through the implementation of ISO, cooperative organisations can increase their efficiency, productivity and profit focusing on less wastage, improved customer retention and acquisition and consistent outcomes, measured and monitored.

Many organisations in Nepal have adopted ISO 9001, 14001, 45001, 22001, 27001 etc. which are globally recognized standards to improve the value of the product and/or service, the sales and marketing advantage, and company requirements. Organisations appreciate how the standard can improve their business processes and reduce scrap, rework and cost (Timsina, 2019).

ISO 9001:2015 specifies requirements for a quality management system where an organization need to demonstrate its ability to consistently provide product that meets customer and applicable statutory and regulatory requirements (ISO, 2015). It defines good management system practices and aims at providing a global standard that spells out quality and trust. The standard is designed to address the delicate balance between maintaining profitability and reducing environmental impact with the commitment of the entire organisation.

\section{ACCESS for Sustainability}

To succeed in today's increasingly competitive environment, credit unions need superior brand intelligence. ACCESS-A1 is the diagnostics tool that would help in developing branding strategies for credit unions capitalizing the competitive advantage. This would also be the basis for 
Association of (ACCU) 's member organizations in providing technical assistance for members to implement the branding strategies and developing advertising materials that will serve as model for credit unions (Kiattisirikumpon, 2020).

ACCESS-A1 Competitive Choice for Excellence in Service and is a well-managed brand can be greater than those of any other business activity (ACCU, 2020). It is believed that the branding strategies will define the role of the Credit Union Movement as a new leader in the Financial Service Sector. In so doing, it will promote those characteristics that differentiate credit unions from other financial institutions in the marketplace. Further, branding will also communicate to a broad national audience that does not realize how closely attuned their values are with those of credit unions. Most importantly, credit union operation will turn around into a dynamic and creative cooperative financial institution (ACCU, 2020).

\section{Objectives}

The objectives of this study were as follows:

1. To assess the clauses of ISO 9001:2015 in the perspective of ACCESS Brand Manual,

2. To compare the ISO clauses with that of ACCESS clauses and

3. To identify the major clauses of ISO 9001 which have more relevancy to the ACCESS manual.

\section{METHODS}

The study was based on literature review of the relevant documents on ISO and ACCESS manuals. During the preparation of this article, a number of practitioners were also interviewed. The content analysis of the text was carried out manually and the gist of the analysis is presented.

\section{FINDINGS AND CONCLUSIONS}

The key findings of this study area are as follows:

\section{Overall Perspective}

Overall perspective of ACCESS manual includes financial perspective, customer perspective, internal business perspective and learning and growth perspective. ISO 9001:2015 is an international standard dedicated to Quality Management Systems (QMS). It outlines a framework for improving quality and a vocabulary of understanding for any organization looking to provide products and services that consistently meet the requirements and expectations of customers and other relevant interested parties in the most efficient manner possible (ASQ, 2015). ISO 9001:2015 doesn't dictate what an organization's objectives should be or how to achieve them. In other words, it doesn't tell anyone how to run their business. It's a flexible standard that allows each organization to define for itself what its objectives and adherence to the standard ought to be. ISO 9001:2015 defines the guiding principles that can be used to create efficiencies by aligning and streamlining processes throughout the organization, in an effort to bring down costs, create new opportunities, 
meet regulatory requirements, and help organizations expand into new markets in which clients demand ISO 9001 certification (Quality Info Center, 2020).

\section{ACCESS and ISO Auditor's Code of Conduct}

Auditor's code of conduct as mentioned in the ACCESS manual includes various parameters such as trust, confidence and credibility, integrity, independence, objectivity and impartiality, political neutrality, conflicts of interests, professional secrecy, competence and professional development. They keep the implementation and practice of ACCESS manual intact. Similarly, ISO 9001:2015 through ISO 19011 has set code of conduct for the practitioners as principles of auditing through integrity, fair presentation, due professional care, confidentiality, independence and evidencebased approach. Both the documents have similar approaches regarding the application of code of conducts for the practitioners.

\section{Brand Development}

ACCESS manual emphasises on the development of action plan, on-going technical assistance, and application of access brand and brand management for the popularity and the effectiveness of the approach. However, ISO 9001 emphasises on comprehensiveness of quality management system following the Plan, Do, Check and Act (PDCA) cycle. AAPD has some similarity with that of ISO schematic process or PDCA.

\section{Financial Indicators}

ACCESS manual has focused more on financial aspects such as protection from delinquent, effective financial structure, quality of asset, rates on return on cost, liquidity and signs of growth. Each of these aspects are changed to indicator level so that the value could be measured. ISO 9001 has not clearly indicated about the financial aspects. It is more on quality management system. However, clause 7.1 emphasises on the need of allocating adequate resources for the QMS. Cls. 7.1.2, 7.2 and 7.2 highlights the importance of human resources, competency and awareness to carry out financial and other activities and cls. 4.4 emphasises on the determination of resources needed for quality management system.

\section{Quality Products and Services}

ACCESS has clearly highlighted the importance of various indicators for the quality products and services. The aim of Quality Management System or ISO 9001 is akin to this need. ACCESS quality products and services indicators include product and service objective, product presentation, range of financial products, brand mind set, wealth building products, capacity building lending, access and convenience, price value, marketing and promotion, loyalty incentives and product packaging. ISO 9001 has many clauses which are similar to such indicators such as clause 8.2.1 customer focus and clause 8.2. requirements for products and services. Other 
clauses such as cls. 4.1 ., cls. 4.2 , cls. 4.3 , cls. 5.1.2 and cls. 8.7 are close to the clauses of ACCESS quality products and services.

\section{Member Satisfaction}

Member's satisfaction depends on various factors. ACCESS believes that to achieve member satisfaction, we should consider various factors such as knowledge of members, building a lasting relation with members, evaluation, share of wallet, institutionalized customer care excellence, member benefits, meetings, member participation, use of wealth building products, use of loan products, understanding of responsibility as measured by delinquency, physical and technological infrastructure, database and management reporting system etc. ISO 9001 has not directly reiterated these indicators but has covered them through various clauses such as cls. 4.4, cls. 7.2, 7.4, 8.5.1., 8.5.5 etc. They include issues such as competence and awareness, customer focused, leadership, infrastructure, equipment, information and communication and software.

\section{Operational Efficiency}

In order to achieve the operational efficiency, ACCESS has highlighted the importance of indicators such as the need of comprehensive operational manual, procedure manual, staff productivity, error management, service delivery to members for loans, deposits and withdrawal, utilization of office machines and equipment and internal communication efficiency. Similar to such criteria, ISO 9001 has included the need of quality manual with policies, competent human resources, tackling nonconformities, control of production and services, post delivery services, infrastructure, internal and external communication etc. through various clauses such as cls. 4.4., 7.1.3, 7.2, 7.4, 8.5.1, 10.2.

\section{Competitive Position}

ACCESS manual has included clarity of vision, boldness of vision, well-defined mission, core values, overarching goals, strategic objectives, annual business plan, sales culture, involvement in the local community, partnership and alliances, relationship with the National Federation, members of the community using the services of the Credit Union, member segmentation according to age, diversity of membership, gender balance, management of regulatory obligations and statutory commitment as the key indicator to achieve competitive position. ISO 9001 has included several clauses which are quite similar to the clauses of competitive position as mentioned in the ACCESS manual. Cls 4 talks about the context of the organisation, cls. 5.1.2 about the customer focus, cls. 5.2. about the establishing quality policy, cls. 6.2. about the quality objectives and planning to achieve them and cls. 10.3 about the continual improvement. Overall aim of the QMS is to meet the statutory and regulatory requirements. 
ISSN: 2362-1303 (Paper) | eISSN: 2362-1311 (Online)

JOURNAL OF ADVANCED ACADEMIC RESEARCH (JAAR)

June 2021

\section{Leadership - Knowledgeable and Involved Board Members}

ACCESS believes that the board is the main decision-maker and it should act as an advisory team. The organisation needs policy manual. External environment should be reviewed. Performance evaluation of the Committees and Board, review of the papers at the Board meeting, developing risk management policy, PEARLS rating should be done. Examination of the Board' accounts and their related parties such as spouse, children etc. should be made mandatory. Interview the CEO and staff regarding the Board performance, coaching and guiding is important. Review the policy and procedures, CEO's job description, Board's nomination process etc. are other important indicators in ACCESS manual. ISO 9001 has several clauses which directly deal with the leadership and competence issues. Cls. 5 talks about leadership and their commitment. Cls. 9 explains about performance evaluation.

\section{Employee Satisfaction}

ACCESS has several indicators focused on the employee satisfaction. It talks about job designs, recruitment and selection, compensation, staffing levels, performance objectives, appraisal standards, performance shared values, team capabilities, career path and development programmes. ISO 9001 includes such issues through cls. 5.2, 5.3, 6.1, 7.2, 9.2 etc. They reiterate the importance of organizational roles, responsibilities and authorities, actions to address risk and opportunities, competence, internal audit etc.

\section{CONCLUSIONS}

The study has concluded that there are many similarities between ACCESS manual and ISO 9001 standard as both focus on overall development and management of the organisations. Both the documents have highlighted the importance of implementing several indicators to maintain the quality of the organisation. Both the standards are compatible with each other. However, they are not completely overlapping in term of the indicators of clauses, they rather complement each other. It can be recommended that for the effective implementation of the ACCESS in the cooperative organisations, it is good to incorporate ISO 9001 as well. It will help the organisation to fully manage itself by implementing quality management system.

Received: 25 June 2021

Accepted: 28 June 2021

Published: 30 June 2021

\section{REFERENCES}

ACCU. (2020). ACCESS: A one competitive choice for excellence in service and soundness. Bangkok: Association of Asian Confederation of Credit Unions .

ASQ. (2015). Quality management systems - Fundamentals and vocabulary. American Society for Quality. 
ISSN: 2362-1303 (Paper) | eISSN: 2362-1311 (Online)

COOP. (2020, November 18). International Cooperative Alliance. (COOP, Editor, COOP, Producer, \& COOP) Retrieved from The history of the cooperative movement: https://www.ica.coop/en/historyco-operative-movement

ISO. (2015). Quality management systems - requirements . Geneva: ISO .

Kiattisirikumpon, K. (2020, Nov. 17). ACCESS Branding Al Competitive Choice for Excellence in Service and Soundness.

Maharjan, U. (2020, January 7). Cooperative movement in Nepal: Still going strong. Kathmandu, Bagmati, Nepal. Retrieved from https://thehimalayantimes.com/opinion/cooperative-movement-in-nepalstill-going-strong/

Quality Info Center. (2020, Nov. 18). Manage quality, risk and compliance. Retrieved from What is ISO 9001:2015 and Why is it Important?: https://www.qualitymag.com/articles/95235-what-is-iso90012015-and-why-is-it-important

Timsina, T. P. (2019). Achieving sustainability through environmental managmeent and policy integration . ICALS Bangladesh. Dhaka. 
ISSN: 2362-1303 (Paper) | eISSN: 2362-1311 (Online)

JOURNAL OF ADVANCED ACADEMIC RESEARCH (JAAR)

Annex: Comparison of Access Auditor's Manual vs. ISO 9001:2015

\begin{tabular}{|c|c|c|}
\hline ACCESS Manual & Remarks & ISO 9001 \\
\hline $\begin{array}{l}\text { Four Perspectives } \\
\text { - Financial Perspective } \\
\text { - Customer Perspective } \\
\text { - Internal Business Perspective } \\
\text { - Learning and Growth Perspective }\end{array}$ & & 5.1.2 Customer Focus \\
\hline $\begin{array}{l}\text { Auditor's Code of Conduct } \\
\text { - Trust, Confidence and Credibility } \\
\text { - Integrity } \\
\text { - Independence, Objectivity and Impartiality } \\
\text { - Political Neutrality } \\
\text { - Conflicts of Interests } \\
\text { - Professional secrecy } \\
\text { - Competence } \\
\text { - Professional Development }\end{array}$ & & $\begin{array}{l}\text { ISO 19011 } \\
\text { Principles of } \\
\text { Auditing } \\
\text { - Integrity } \\
\text { - Fair Presentation } \\
\text { - Due Professional } \\
\text { Care } \\
\text { - Confidentiality } \\
\text { - Independence } \\
\text { - Evidence-based } \\
\text { Approach }\end{array}$ \\
\hline $\begin{array}{l}\text { Assess Audit Process Diagram } \\
\text { - Development of Action Plan } \\
\text { - On-Going Technical Assistance } \\
\text { - Application for Access Brand } \\
\text { - Brand Management }\end{array}$ & & $\begin{array}{l}\text { AAPD - Similar to } \\
\text { ISO Schematic } \\
\text { Process } \\
\text { Diagram/PDCA }\end{array}$ \\
\hline $\begin{array}{l}\text { Access Branding at a Glance } \\
\text { - Financial } \\
\text { - Customers/Members } \\
\text { - Internal Business Processes } \\
\text { - Knowledge and Learning }\end{array}$ & & $\begin{array}{l}\text { Cls. 4. Context of the } \\
\text { Organisation } \\
\text { 7.1.6. Organisational } \\
\text { knowledge }\end{array}$ \\
\hline \multicolumn{3}{|c|}{ Access Indicators } \\
\hline $\begin{array}{l}\text { 1. Financial Perspective } \\
\text { PROTECTION } \\
\text { 1.1. P1. Provisions for Delinquent Loans over } 12 \\
\text { Months } \\
\text { 1.2. P2. Provisions for Delinquent Loans } 1-12 \\
\text { Months } \\
\text { EFFECTIVE FINANCIAL STRUCTURE } \\
\text { 1.3. E1. Net Loans/Total Assets (Goal: Between } \\
\text { 70-80\%) }\end{array}$ & & $\begin{array}{l}\text { ISO } 9001: 2015 \text { does } \\
\text { not directly talk about } \\
\text { finance. It is more on } \\
\text { quality management } \\
\text { system. However, } \\
\text { clause } 7.1 \text { emphasises } \\
\text { on the need of } \\
\text { allocating adequate } \\
\text { resources for the } \\
\text { QMS. Cls. } 7.1 .2,7.2 \\
\text { and } 7.2 \text { highlights the } \\
\text { importance of human } \\
\text { resources, }\end{array}$ \\
\hline
\end{tabular}

Vol. 8. No. I 
ISSN: 2362-1303 (Paper) | eISSN: 2362-1311 (Online)

JOURNAL OF ADVANCED ACADEMIC RESEARCH (JAAR)

June 2021

\begin{tabular}{|c|c|c|}
\hline $\begin{array}{l}\text { 1.4. E5. Savings Deposits/Total Assets (Goal: } \\
\text { Between 70-80\%) } \\
\text { 1.5. E6. External Borrowing to Total Assets - } \\
\text { Reducing to Zero } \\
\text { 1.6. E9. Net Institutional Capital (Goal: } \\
\text { Minimum 10\%) } \\
\text { ASSET QUALITY } \\
\text { 1.7. A1. Total Loan Delinquency/Total Loan } \\
\text { Portfolio (Goal: Equal or Less Than 5\%) } \\
\text { 1.8. A2. Non-Earning Assets/Total Assets (goal: } \\
\text { Less than or Equal to 5\%) } \\
\text { RATES ON RETURN ON COST } \\
\text { 1.9. R7. Interest Cost on Share Capital to } \\
\text { average Shares (Goal: Market Rate or > R5 } \\
\text { 1.10.R9. Operating Expenses to Average Assets } \\
\text { (Goal: 5\%) } \\
\text { LIQUIDITY } \\
\text { 1.11.L1. Liquid Investments (+) Liquid assets (-) } \\
\text { Short-Term Payables/Savings Deposits } \\
\text { (Goal: Minimum 15\%) } \\
\text { SIGNS OF GROWTH } \\
\text { 1.12. S10. Growth in Membership (Goal: > 12\% } \\
\text { than the Inflation Rate) }\end{array}$ & & $\begin{array}{l}\text { competency and } \\
\text { awareness to carry } \\
\text { out financial and } \\
\text { other activities. Cls. } \\
4.4 \text { emphasises on the } \\
\text { determination of } \\
\text { resources needed for } \\
\text { quality management } \\
\text { system. }\end{array}$ \\
\hline \multicolumn{3}{|c|}{ CUSTOMER MEMBERSHIP PERSPECTIVE } \\
\hline \multicolumn{3}{|c|}{$\begin{array}{l}\text { C1. Quality Products and Services } \\
\end{array}$} \\
\hline 2.1. Product and Service Objective & $\begin{array}{l}\text { Find out the way by which } \\
\text { members' feedback are } \\
\text { gathered. Responding to } \\
\text { members. }\end{array}$ & $\begin{array}{l}\text { 8.2.1. Customer } \\
\text { communication }\end{array}$ \\
\hline 2.2. Product Presentation & $\begin{array}{l}\text { Product catalogue and } \\
\text { product brochures }\end{array}$ & $\begin{array}{l}\text { 8.2. Requirements for } \\
\text { products and services }\end{array}$ \\
\hline 2.3. Range of Financial Products & $\begin{array}{l}\text { Assessment of the } \\
\text { demographics of members }\end{array}$ & $\begin{array}{l}\text { Cls. } 4.1 \text {. } \\
\text { Understanding the } \\
\text { organisation and its } \\
\text { context. }\end{array}$ \\
\hline
\end{tabular}


ISSN: 2362-1303 (Paper) | eISSN: 2362-1311 (Online)

JOURNAL OF ADVANCED ACADEMIC RESEARCH (JAAR)

June 2021

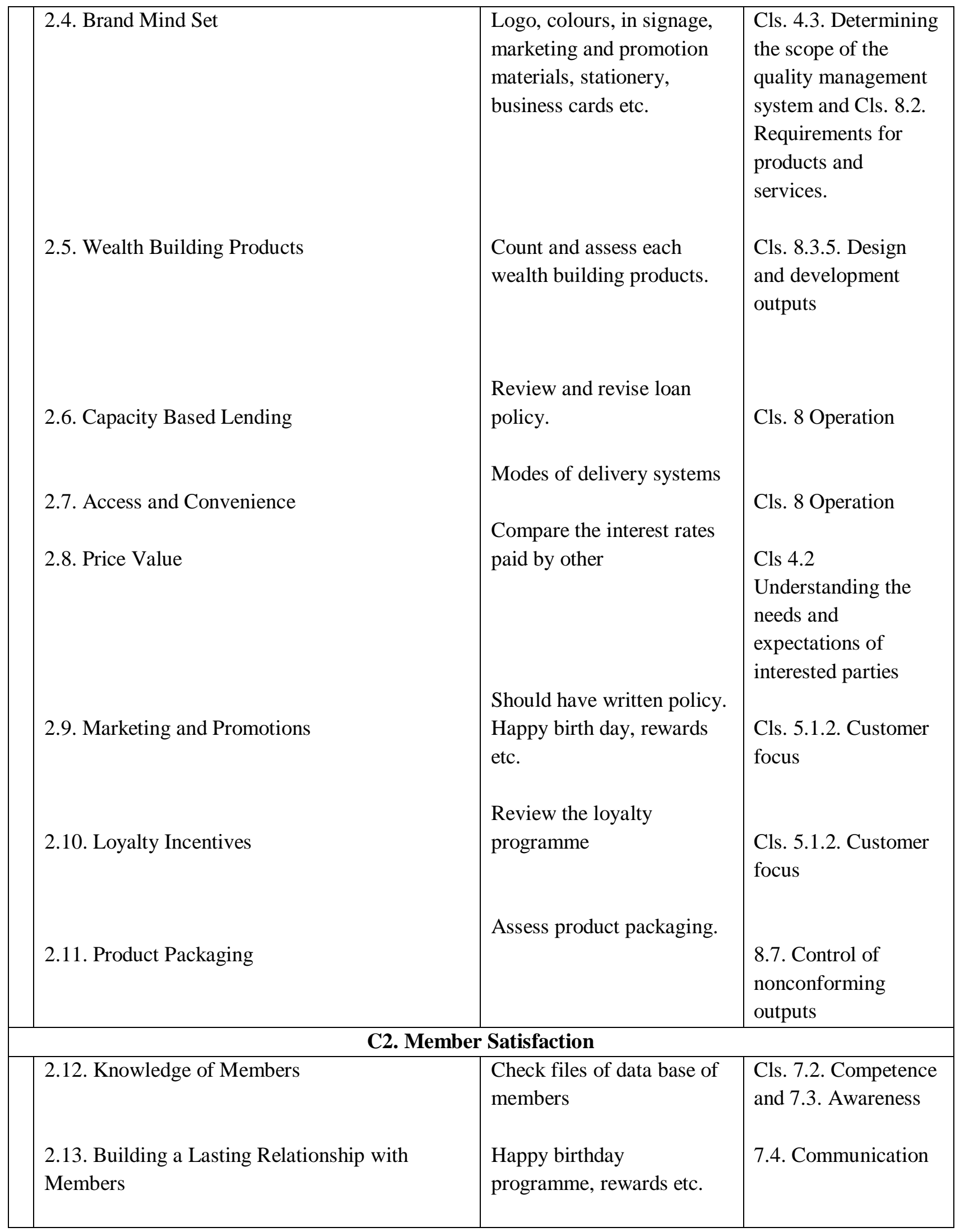


ISSN: 2362-1303 (Paper) | eISSN: 2362-1311 (Online)

JOURNAL OF ADVANCED ACADEMIC RESEARCH (JAAR)

June 2021

2.14. Member Satisfaction Evaluation

2.15. Share of Wallet

2.16. Institutionalised Customer Care Excellence

2.17. Member Benefits

2.18. General Meetings

2.19. Member Participation

2.20. Use of Wealth Building Products

\subsection{Use of Loan Products}

2.22. Understanding of Responsibility as Measured by Delinquency
Membership meetings, customer survey, use

benchmark

Analyse maintenance of saving accounts by members

Customer orientation, follow customer care guidelines

Scholarship, medical, dental, pension, new born, calamities etc.

General meeting attendance, by-laws, date, quorum etc.

Suggestions from members

Usage of saving products by members

Usage of loan products by members

Analyse schedule of delinquency

Observe the office environment
Overall 9001 is customer focused, Cls. 5.1.2 - Customer focused

Cls. 7.3 - Customer awareness

Cls. 8.2.3. Review of the requirements for products and services and Cls. 8.3.2.

Design and development planning

Cls. 5 - Leadership

Cl. 7.3. - Awareness

Cls. 4.2. The organisation shall monitor and review information about the interested parties and their requirements.

Cls. 10.2.

Nonconformities and corrective action. 
ISSN: 2362-1303 (Paper) | eISSN: 2362-1311 (Online)

JOURNAL OF ADVANCED ACADEMIC RESEARCH (JAAR)

\begin{tabular}{|c|c|c|}
\hline $\begin{array}{l}\text { 2.23. Physical Infrastructure - Buildings and } \\
\text { Office Space } \\
\text { 2.24. Technological Infrastructure - Telephone } \\
\text { and Fax } \\
\text { 2.25. Computers, Applications, Network and E- } \\
\text { mail. }\end{array}$ & $\begin{array}{l}\text { Observe the usage of the } \\
\text { available technology } \\
\text { Observe the usage of the } \\
\text { available technology }\end{array}$ & $\begin{array}{l}\text { Cls. 7.1.3. - } \\
\text { Infrastructure } \\
\text { Cls. 7.1.3.b - } \\
\text { Equipment } \\
\text { Cls. 7.1.3.d - } \\
\text { Information and } \\
\text { Communication } \\
\text { Cls. 7.1.3.b - } \\
\text { Software } \\
\text { Cls. 7.1.3b and d. } \\
\text { Maintain equipment, } \\
\text { both hardware and } \\
\text { software and } \\
\text { information and } \\
\text { communication } \\
\text { technology }\end{array}$ \\
\hline \multicolumn{3}{|c|}{$\begin{array}{l}\text { INTERNAL BUSINESS PERSPECTIVE } \\
\text { IBP 1. OPERATIONAL EFFICIENCY }\end{array}$} \\
\hline \multicolumn{3}{|l|}{ OPERATIONAL } \\
\hline 3.1. Comprehensive Operational Manual & $\begin{array}{l}\text { Review existing operational } \\
\text { manual }\end{array}$ & $\begin{array}{l}\text { Cls. 4.4. ISO } 9001 \\
\text { also requires Quality } \\
\text { Manual }\end{array}$ \\
\hline 3.2. Procedures Manual & $\begin{array}{l}\text { Develop and follow } \\
\text { comprehensive procedures } \\
\text { manual }\end{array}$ & $\begin{array}{l}\text { Cls. 4.4.1. Quality } \\
\text { Manual with policies }\end{array}$ \\
\hline 3.3. Staff Productivity & $\begin{array}{l}\text { Compute the ratio of staff } \\
\text { with the total membership }\end{array}$ & $\begin{array}{l}\text { Cls. } 7.2 . \mathrm{b}- \\
\text { Competent human } \\
\text { resources }\end{array}$ \\
\hline 3.4. Error Management & $\begin{array}{l}\text { See and review the error } \\
\text { management system }\end{array}$ & $\begin{array}{l}\text { Cls. } 10.2 \text {. } \\
\text { Nonconformity and } \\
\text { corrective actions }\end{array}$ \\
\hline 3.5. Service Delivery to Members - Loans & $\begin{array}{l}\text { Review the loan policy, } \\
\text { systems and procedures }\end{array}$ & $\begin{array}{l}\text { Cls. 8.5.1. - Control } \\
\text { of production and } \\
\text { service provision }\end{array}$ \\
\hline
\end{tabular}


ISSN: 2362-1303 (Paper) | eISSN: 2362-1311 (Online)

JOURNAL OF ADVANCED ACADEMIC RESEARCH (JAAR)

\begin{tabular}{|c|c|c|}
\hline 3.6. Service Delivery to Members - Deposits & $\begin{array}{l}\text { Review the savings policy, } \\
\text { systems and procedures, } \\
\text { find out the turnaround }\end{array}$ & $\begin{array}{l}\text { Cls. 8.5.1. - Control } \\
\text { of production and } \\
\text { service provision }\end{array}$ \\
\hline 3.7. Service Delivery to Members - Withdrawal & $\begin{array}{l}\text { Review the procedures for } \\
\text { withdrawals, process }\end{array}$ & $\begin{array}{l}\text { Cls. 8.5.5. }- \text { Post- } \\
\text { delivery activities }\end{array}$ \\
\hline $\begin{array}{l}\text { 3.8. Utilization of Office Machines and } \\
\text { Equipment }\end{array}$ & $\begin{array}{l}\text { Observe and interview staff } \\
\text { on the use, handling and } \\
\text { maintenance }\end{array}$ & $\begin{array}{l}\text { Cls. 7.1.3.b - } \\
\text { Infrastructure }\end{array}$ \\
\hline 3.9. Internal Communication Efficiency & $\begin{array}{l}\text { Shall have a comprehensive } \\
\text { policy and procedures on } \\
\text { internal communication }\end{array}$ & $\begin{array}{l}\text { Cls. 7.4. - } \\
\text { Communication } \\
\text { (internal and } \\
\text { external) }\end{array}$ \\
\hline \multicolumn{3}{|c|}{ IBP 2. COMPETITIVE POSITION } \\
\hline 3.10. Clarity of Vision & $\begin{array}{l}\text { Review the vision } \\
\text { statement }\end{array}$ & $\begin{array}{l}\text { Cls. 5.2. - } \\
\text { Establishing quality } \\
\text { policy }\end{array}$ \\
\hline 3.11. Boldness of Vision & Assess the vision statement & $\begin{array}{l}\text { Cls. 5.2. - } \\
\text { Establishing quality } \\
\text { policy }\end{array}$ \\
\hline 3.12. Well-Defined Mission & $\begin{array}{l}\text { Assess the mission } \\
\text { statement }\end{array}$ & $\begin{array}{l}\text { Cls. 5.2. - } \\
\text { Establishing quality } \\
\text { policy }\end{array}$ \\
\hline 3.13. Core Values & $\begin{array}{l}\text { Review planning document } \\
\text { and marketing materials }\end{array}$ & $\begin{array}{l}\text { Cls. 5.2. - } \\
\text { Establishing quality } \\
\text { policy }\end{array}$ \\
\hline 3.14. Overarching Goals & Goals should be SMART & $\begin{array}{l}\text { Cls. 6.2. - Quality } \\
\text { objectives and } \\
\text { planning to achieve } \\
\text { them }\end{array}$ \\
\hline 3.15. Strategic Objectives & Assess strategies & $\begin{array}{l}\text { Cls. 6.2. Quality } \\
\text { objectives and } \\
\text { planning to achieve } \\
\text { them }\end{array}$ \\
\hline & & Same cls. 6.2 \\
\hline
\end{tabular}


ISSN: 2362-1303 (Paper) | eISSN: 2362-1311 (Online)

JOURNAL OF ADVANCED ACADEMIC RESEARCH (JAAR)

June 2021

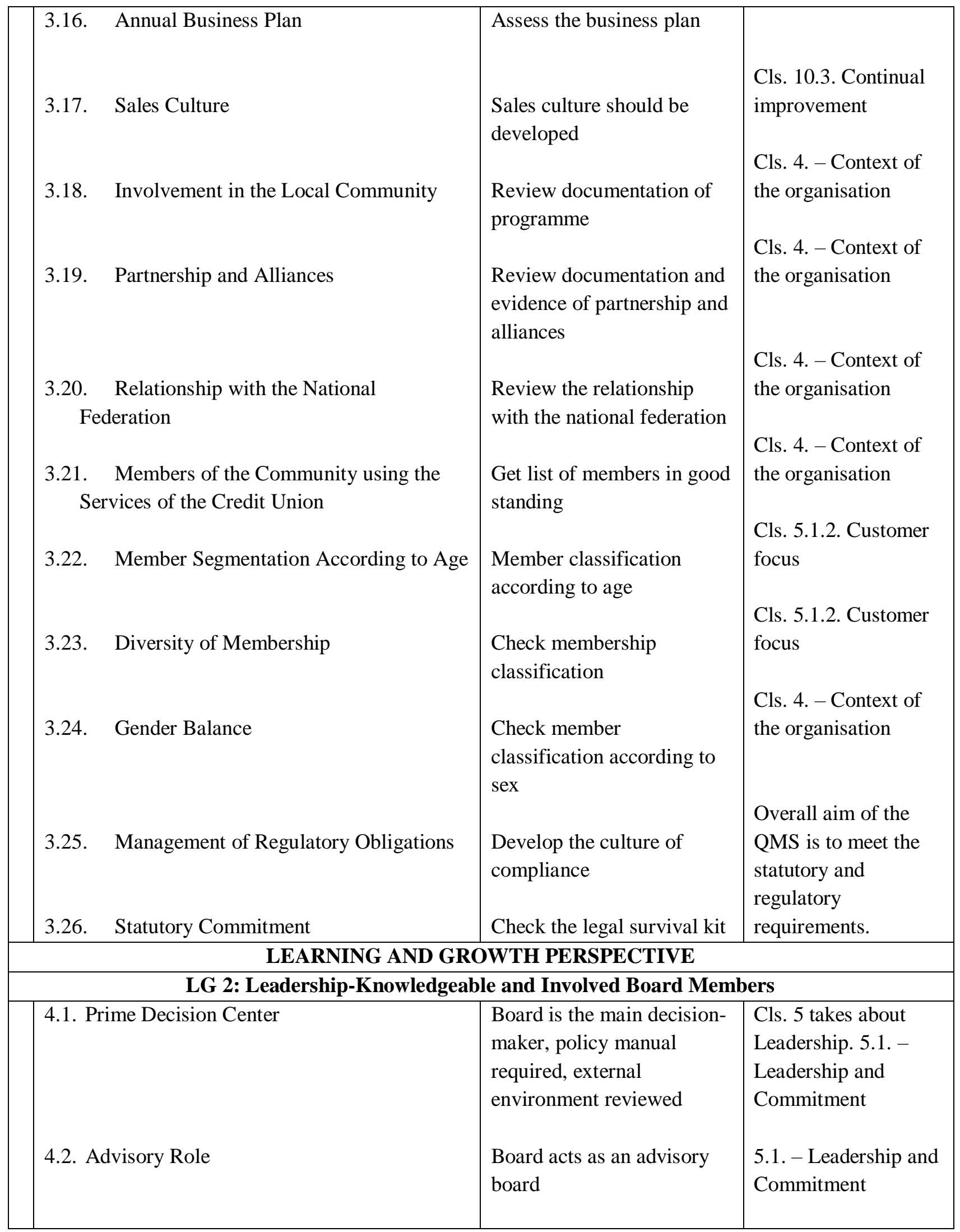


ISSN: 2362-1303 (Paper) | eISSN: 2362-1311 (Online)

JOURNAL OF ADVANCED ACADEMIC RESEARCH (JAAR)

June 2021

\begin{tabular}{|c|c|c|}
\hline 4.3. Perpetuating & $\begin{array}{l}\text { Performance evaluation of } \\
\text { the Committees and Board, } \\
\text { training }\end{array}$ & $\begin{array}{l}\text { 5.1. - Leadership and } \\
\text { Commitment }\end{array}$ \\
\hline 4.4. Trustee Function & $\begin{array}{l}\text { Review the papers at the } \\
\text { Board meeting, Risk } \\
\text { management policy, } \\
\text { PEARLS rating }\end{array}$ & $\begin{array}{l}\text { 5.1. - Leadership and } \\
\text { Commitment }\end{array}$ \\
\hline 4.5. Symbolic & $\begin{array}{l}\text { Examination of the Board' } \\
\text { accounts and their related } \\
\text { parties such as spouse, } \\
\text { children etc. }\end{array}$ & $\begin{array}{l}\text { 5.1. - Leadership and } \\
\text { Commitment }\end{array}$ \\
\hline 4.6. Composition and Commitment & $\begin{array}{l}\text { Examination of the Board' } \\
\text { accounts and their related } \\
\text { parties such as spouse, } \\
\text { children etc. }\end{array}$ & $\begin{array}{l}\text { 5.1. - Leadership and } \\
\text { Commitment }\end{array}$ \\
\hline 4.7. Guiding and Coaching & $\begin{array}{l}\text { Interview the CEO and } \\
\text { staff, how Board perform } \\
\text { coaching and guiding. }\end{array}$ & $\begin{array}{l}\text { 5.1. - Leadership and } \\
\text { Commitment }\end{array}$ \\
\hline 4.8. Governance & $\begin{array}{l}\text { Review the policy and } \\
\text { procedures, CEO's job } \\
\text { description, Board's } \\
\text { nomination }\end{array}$ & $\begin{array}{l}\text { 5.1. - Leadership and } \\
\text { Commitment }\end{array}$ \\
\hline 4.9. Performance Evaluation & $\begin{array}{l}\text { Examination of the Board's } \\
\text { performance }\end{array}$ & $\begin{array}{l}\text { Cls. } 9 \text { - Performance } \\
\text { Evaluation }\end{array}$ \\
\hline 4.10. Performance Evaluation & $\begin{array}{l}\text { Examination of the list of } \\
\text { Board of Directors } \\
\text { (Gender) }\end{array}$ & $\begin{array}{l}\text { Cls. } 5 \text { (Leadership) } \\
\text { and Cls. } 9 \\
\text { (Performance } \\
\text { evaluation) }\end{array}$ \\
\hline \multicolumn{3}{|c|}{ LG 2: Employee Satisfaction } \\
\hline 4.11. Job Designs & $\begin{array}{l}\text { Evaluate the Mgmt. } \\
\text { structure and JD of the } \\
\text { existing organizational } \\
\text { function }\end{array}$ & $\begin{array}{l}\text { Cls. 5.3. - } \\
\text { Organisational roles, } \\
\text { responsibilities and } \\
\text { authorities }\end{array}$ \\
\hline 4.12. Recruitment and Selection & & \\
\hline
\end{tabular}


ISSN: 2362-1303 (Paper) | eISSN: 2362-1311 (Online)

JOURNAL OF ADVANCED ACADEMIC RESEARCH (JAAR)

June 2021

\begin{tabular}{|c|c|c|c|}
\hline & & $\begin{array}{l}\text { Examination of employee } \\
\text { policy and processes }\end{array}$ & $\begin{array}{l}\text { Cls. 5.2. Establishing } \\
\text { the quality policy }\end{array}$ \\
\hline 4.13. & Compensation & $\begin{array}{l}\text { Comparing compensation } \\
\text { package with others }\end{array}$ & $\begin{array}{l}\text { Cls. 6.1. Actions to } \\
\text { address risks and } \\
\text { opportunities }\end{array}$ \\
\hline 4.14 . & Staffing Levels & $\begin{array}{l}\text { Examining staff record on } \\
\text { resignation for the last } 5 \\
\text { years }\end{array}$ & $\begin{array}{l}\text { Cls. 9.2. Internal } \\
\text { audit }\end{array}$ \\
\hline 4.15 . & Performance Objectives & $\begin{array}{l}\text { Examine performance } \\
\text { evaluation system }\end{array}$ & $\begin{array}{l}\text { Cls. } 9 \text { - Performance } \\
\text { Evaluation }\end{array}$ \\
\hline 4.16. & Appraisal Standards & $\begin{array}{l}\text { Analyse the practices, } \\
\text { policies and guidelines }\end{array}$ & $\begin{array}{l}\text { Cls. } 9 \text { - Performance } \\
\text { Evaluation. Cls. } 9.2- \\
\text { Internal Audit }\end{array}$ \\
\hline 4.17. & Performance as Shared Values & $\begin{array}{l}\text { Analyse the practices, } \\
\text { policies and guidelines }\end{array}$ & $\begin{array}{l}\text { Cls. 9.2. Internal } \\
\text { audit }\end{array}$ \\
\hline 4.18. & Team Capabilities & Interview the staff & $\begin{array}{l}\text { Cls. } 7.2- \\
\text { Competence }\end{array}$ \\
\hline $\begin{array}{l}4.19 \text {. } \\
4.20 \text {. }\end{array}$ & $\begin{array}{l}\text { Career Path } \\
\text { Development Programme }\end{array}$ & $\begin{array}{l}\text { Interview the staff } \\
\text { Check the HR policy }\end{array}$ & $\begin{array}{l}\text { Cls. 7.2. Competence } \\
\text { Cls. 9.2. Internal } \\
\text { audit }\end{array}$ \\
\hline
\end{tabular}

